\title{
ANALISIS KEMAMPUAN LITERASI MATEMATIKA SISWA KELAS VIII SMP SWASTA DI KOTA KENDARI
}

\author{
Nadilla Kadissa Astuti ${ }^{(1)}$ Fahinu $^{2)}$, Jafar Masuha ${ }^{3)}$ \\ ${ }^{1)}$ Alumni Jurusan Pendidikan Matematika, ${ }^{2,3)}$ Dosen Jurusan Pendidikan Matematika \\ FKIP Universitas Halu Oleo Email: nadillakadis@ gmail.com; \\ fahinuf@yahoo.com; jafar665@yahoo.co.id
}

\begin{abstract}
Abstrak
Penelitian ini bertujuan untuk mendeskripsikan kemampuan literasi matematika siswa kelas VIII SMP Swasta di kota Kendari berdasarkan level literasi matematika, domain konten dan konteks. Populasi dalam penelitian ini adalah seluruh siswa kelas VIII SMP Swasta terakreditasi yang tersebar pada delapan sekolah swasta dikotaKendari. Teknik pengambilan sampel menggunakan teknik purposive sampling.Teknik pengumpulan data dilakukan dengan pemberian instrumen tes kemampuan literasi matematika berbentuk tes uraian.Teknik analisis data menggunakan analisis deskriptif. Berdasarkan hasil analisis data diperoleh kesimpulan bahwa kemampuan literasi matematika siswa kelas VIII SMP Swasta di kota Kendari termasuk kategori kurang sekali, dibuktikan dengan rata-rata perolehan nilai siswa di delapan sekolah hanya mencapai 19,87 . Selanjutnya bila dikaji berdasarkan level, siswa unggul dilevel 2 dan kurang dilevel 6. Berdasarkan domain konten, siswa unggul konten shape and space dan kurang konten quantity. Berdasarkan domain konteks siswa unggul konteks personaldan kurang konten societal.
\end{abstract}

Kata kunci: literasi matematika, level, konten

\section{ANALYSIS OF MATHEMATICS LITERACY ABILITY OF STUDENTS CLASS VIII SMP SWASTA IN KOTA KENDARI}

\begin{abstract}
This study aims to describe the ability of mathematics literacy of students class VIII SMP Swasta in kota Kendari based on the level of mathematics literacy, content domain and context. The population in this study is the all students of class VIII in the accredited SMP Swasta that are scattered in eight private schools in kota Kendari. Techniques of data sampling use a purposive sampling technique. Technique of data collection is done by giving instrument test of mathematics literacy ability in the form of description test. Technique of data analysis uses descriptive analysis. Based on the results of data analysis that have been obtained, it gives conclusion that the ability of mathematics literacy of students class VIII SMP Swasta in kota Kendari can be categorized as very less, the evidence can be seen from the average acquisition value of students in eight schools that just reach 19,87 . Furthermore, when it is examined based on the level, the students are superior in level 2 and less in level 6. Based on the domain of content, the students are superior in shape and space content and less in quantity content. Based on the domain of context, the students are superior in personal context and less in societal content.
\end{abstract}

Keywords: The Ability of Mathematical Literacy, Level, Content 


\section{Pendahuluan}

Pendidikan adalah salah satu item yang sangat berpengaruh di era globalisasi saat ini.Sehingga tak heran, pendidikan terus mengalami perubahan. Sebuah negara memerlukan pendidikan untuk meningkatkan kemajuan perkembangan bangsanya sehingga dapat bersaing dengan bangsa lain. Hal ini menyebabkan setiap negara merancang dengan sistematis setiap sistem pendidikannya untuk mendapatkan hasil yang maksimal dalam berbagai bidang studi terutama dalam bidang studi matematika.Hudojo menyatakan bahwa matematika merupakan ide-ide abstrak yang diberi simbol-simbol yang tersusun secara hirarkis dan penalarannya deduktif, sehingga belajar matematika itu merupakan kegiatan mental yang tinggi (Hasratuddin, 2014: 30).Matematika termasuk dalam pengklasifikasian ilmu penalaran yang logik yaitu kelompok ilmu pengetahuan yang lebih mementingkan pemahaman konsep dari pada penghafalan.Hal ini sangatlah penting agar siswa dapat menerapkan konsep-konsep tersebut untuk memecahkan masalah dalam berbagai segi kehidupan.Matematika yang digunakan dalam berbagai segi kehidupan disebut literasi matematika (Johar, 2012: 32).

\begin{tabular}{llcr}
\multicolumn{1}{c}{ Literasi } & matematika merupakan \\
pengetahuan & untuk & mengetahui & dan \\
menggunakan & dasar & matematika & dalam
\end{tabular}
kehidupan sehari-hari (Ojose, 2011: 90). Pendapat ini menekankan pada penggunaan kemampuan matematika.Menurut Mathematics Framework PISA 2015 (OECD, 2016: 4) Literasi matematika didefinisikan sebagai kemampuan seorang individu merumuskan, menggunakan, menafsirkan matematika dalam berbagai konteks.Termasuk didalamnya bernalar secara matematis dan menggunakan konsep, prosedur, fakta dan alat matematika dalam menjelaskan suatu fenomena.Istilah literasi matematika yang dicetuskan oleh NCTM (National Council of Teachers Mathematics) mendefinisikan bahwa terdapat lima kompetensi dalam pembelajaran matematika, yaitu: pemecahan masalah matematis, komunikasi matematis, penalaran matematis, koneksi matematis dan representasi matematis. Kemampuan yang mencakup kelima kompetensi tesebut adalah kemampuan literasi matematika (Maryanti, 2012: 5)
Asesmen berskala internasional yang digunakan untuk menilai kemampuan literasi matematika siswa usia 15 tahun dalam matematika yaitu PISA (Program for International StudentAssessment). PISA dilaksanakan secara reguler sekali dalam tiga tahun sejak tahun 2000 untuk mengetahui literasi, sains dan membaca.Dalam pelaksanaannya PISA dikembangkan oleh beberapa negara maju di dunia yang tergabung dalam the Organization for Economic Cooperation and Development (OECD) yang berkedudukan di negara Perancis.Fokus dari PISA adalah literasi yang menekankan pada keterampilan dan kompetensi yang diperoleh siswa dari sekolah dan dapat digunakan dalam kehidupan sehari-hari.Hal ini menunjukkan pentingnya untuk mengaktifkan kemampuan literasi matematika agar siswa dapat merasakan peranan dan manfaat dari pembelajaran matematika yang mereka peroleh di sekolah.

Pentingnya literasi matematika ini, ternyata belum sejalan dengan prestasi siswa Indonesia di kanca internasional. Adapun hasil pencapaian Indonesia khusus bidang matematika tahun 2000, Indonesia menduduki peringkat 39 dari 41 negara yang berpartisipasi dengan skor siswa 367, tahun 2003 Indonesia menduduki peringkat 38 dari 40 negara yang berpartisipasi dengan skor siswa 360, tahun 2006 Indonesia menduduki peringkat 50 dari 57 negara yang berpartisipasi dengan skor siswa 391, tahun 2009 Indonesia menduduki peringkat 61 dari 68 negara yang berpartisipasi dengan skor siswa 371, tahun 2012 Indonesia menduduki peringkat 64 dari 65 negara yang berpartisipasi dengan skor siswa 375, selanjutnya tahun 2015 Indonesia menduduki peringkat 63 dari 70 negara yang berpartisipasi dengan skor siswa 386. Meskipun hasil studi PISA terakhir yakni tahun 2015 mengalami peningkatan skor dibandingkan studi tahun-tahun sebelumnya, namun rata-rata skor tersebut masih berada di bawah rata-rata skor internasional, yakni 490 (OECD, 2018: 5).Fakta ini menunjukkan belum ada perubahan yang signifikan terhadap kemampuan literasi matematika siswa Indonesia dan rendahnya kemampuan siswa dalam studi internasional ini menunjukkan kurangnya perhatian siswa untuk meningkatkan potensi yang dimilikinya, potensi yang dimaksud dalam hal literasi matematika. 
Selain itu, meskipun kemampuan literasi matematika siswa Indonesia secara internasional telah tergambarkan dalam penelitian PISA, namun upaya pemetaannya secara detail di setiap wilayah belum dilakukan.Wulandari dan Jailani (2015) menjelaskan bahwa sampel sekolah yang digunakan pada penelitian PISA di Indonesia menggunakan sekolah-sekolah dengan kategori rendah sehingga belum menggambarkan karakteristik sebenarnya dari kemampuan literasi matematika siswa Indonesia (Hamidy, 2016: 8).Oleh karena itu, untuk menggambarkan karakteristik sebenarnya dari kemampuan literasi matematika siswa Indonesia, saat ini telah dilakukan beberapa penelitian oleh mahasiswa yang tersebar di seluruh Indonesia maupun penelitian yang dilakukan oleh Kemendikbud. Salah satunya yaitu penelitian yang dilakukan oleh Mahdiansyah dan Rahmawati (2014) dari penelitian tersebut memberikan gambaran bahwa dari beberapa wilayah capain literasi matematika untuk Sulawesi Tenggara yang diwakili oleh kota Kendari memperoleh skor yaitu sebesar 19,4. Jika dibandingkan kota-kota lainnya, skor literasi matematika untuk kota Kendari memperoleh skor terendah.

Kota Kendarisebagai ibu kota provinsi Sulawesi Tenggara belum memiliki kejelasan lebih mendalam mengenai gambaran kemampuan literasi matematika siswa, walaupun dari penelitian yang dilakukan oleh Mahdiansyah dan Rahmawati (2014), kota Kendari memperoleh skor yaitu 19,4 (skala 50), perlu dilakukan penelitian secara menyeluruh untuk mengetahui level literasi matematika, domain konten, konteks dan karekteristik butir soal yang belum terpenuhi. Penelitian ini berfokus pada kemampuan literasi matematika siswa SMP Swasta, hal ini didasarkan pada prestasi antara siswa sekolah swasta dengan sekolah negeri menunjukkan perbedaan yang signifikan, ternyata jika dibandingkan sekolah negeri, capaian prestasi sekolah swasta jauh lebih tertinggal. Oleh karena itu, perlu dilakukan penelitian lebih lanjut untuk mengetahui bagian permasalahan mana yang belum tercapai sesuai dengan kriteria yang telah ditetapkan secara nasional serta untuk tindak lanjut ke depan dalam rangka perbaikan bagi materi yang belum terpenuhi. Penelitian ini sangat penting untuk memberi kejelasan kepada guru-guru matematika SMP Swasta di kota Kendariterkait gambaran kemampuan literasi matematika siswanya dan sebagai tolak ukur kesiapan generasi bangsa menghadapi globalisasi. Dengan demikian, hasil dari penelitian ini dapat menjadi gambaran kualitas generasi masa depan sekaligus pertimbangan dalam mengambil kebijakan terhadap kurikulum pendidikan SMP Swasta di kota Kendari secara khusus, di Indonesia secara umum.

Permasalahan yang dihadapi dalam berbagai situasi kehidupan sehari-hari pada dasarnya memiliki ciri sebagaimana sifat dari fenomena matematika, terdapat berbagai macam permasalahan dan diperlukan proses tingkat tinggi untuk menyelesaikan permasalahan tersebut. Oleh karena itu, OECD (2009: 21-36) menambahkan bahwa PISA meliputi tiga komponen mayor dari domain matematika, yaitu konten, konteks dan level literasi matematika.

Sesuai dengan tujuan PISA untuk menilai kemampuan siswa menyelesaikan masalah real, maka masalah pada PISA meliputi konten (content) matematika yang berkaitan dengan fenomena yang terdiri dari Change and Relationships (Perubahan dan Hubungan), 2) Space and Shape (Ruang dan Bentuk), 3) Quantity(Bilangan), 4) Uncertainty and Data (Probabilitas/Ketidakpastian dan Data).

Masalah dan penyelesaiannya bisa muncul dari situasi atau konteks yang berbeda berdasarkan pengalaman individu.Oleh karena itu, soal-soal yang diberikan dalam PISA disajikan sebagian besar dalam situasi dunia nyata sehingga dapat dirasakan manfaat matematika untuk memecahkan permasalahan kehidupan keseharian.Dalam PISA mengkategorikan konteks menjadi 4 bagian yaitu: a) Personal (konteks pribadi), b) Occupational (konteks pekerjaan),c) Societal (konteks umum), d) Scientific (konteks ilmiah),

Kemampuan matematika siswa dalam PISA (OECD 2014 dalam Johar, 2012: 36) dibagi menjadi enam level (tingkatan). Setiap level tersebut menunjukkan tingkat kompetensi matematika yang dicapai siswa.Karakteristik Level 1yaitu Konteksnya umum, informasi yang relevan dengan pertanyaan yang jelas, dapat diselesaikan sesuai dengan stimulus yang diberikan.Karakteristik Level 2 yaitu mengenali situasi dengan inferensi langsung, memilah informasi yang relevan dari sumber yang tunggal, melaksanakan prosedur dan memberikan alasan.Karakteristik Level 3yaitumelaksanakan prosedur dengan baik, memerlukan strategi pemecahan masalah, 
memila informasi yang relevan dari sumber yang berbeda, memberikan alasan.Karakteristik Level 4 yaitu memerlukan penyelesaian yang efektif dalam situasi yang kongkrit tetapi kompleks, memilah informasi yang relevan dari sumber yang berbeda dan menghubungkan dalam situasi yang nyata, menggunakan keterampilan dan mengemukakan alasan.Karakteristik Level 5 yaitu bekerja dengan menggunakan situasi yang kompleks, mengetahui kendala yang dihadapi, melakukan dugaan, memilih, membandingkan dan mengevaluasi strategi pemecahan masalah.Karakteristik Level 6 yaitu melakukan konseptualisasi dan generalisasi dengan menggunakan informasi pada situasi yang kompleks, menghubungkan informasi yang berbeda, mampu berpikir dan bernalar secara matematika, mampu berargumantasi dan menafsir secara dewasa.

\section{Metode}

Penelitian ini adalah penelitian deskriptif dengan perolehan data menggunakan deskriptif kuantitatif.Perhatian utama dalam penelitian ini adalah hasil Tes Kemampuan Literasi Matematika Siswa. Analisis tes hasil pekerjaan siswa tersebut akan menyajikan jawaban terhadap permasalahan penelitian ini. Penelitian ini dilaksanakan pada semester genap tahun ajaran 2017/2018 di delapan SMP Swasta di kota Kendari.

Populasi dalam penelitian ini adalah seluruh siswa kelas VIII SMP Swasta terakreditasi yang tersebar di kota Kendari. Teknik pengambilan sampel menggunakan teknik purposive sampling. Pengambilan sampel tersebut dijelaskan sebagai berikut. Seluruh Siswa kelas VIII SMP yang tersebar di delapan sekolah swasta terakreditasi di kota Kendari. Dari setiap sekolah diambil 30\% dari jumlah keseluruhan siswa kelas VIII, sehingga diperoleh 22 siswa SMP Frater kendari, 39 Siswa SMP Kartika Jaya Kendari, 4 siswa SMP
Hasrati kendari, 13 siswa SMP Ilmiah Kendari, 4 Siswa SMP Integral Hidayatullah, 9 siswa SMP Satria Kendari, 19 siswa SMP Tahfidzul Qur`an Mu`adz Bin Jabal dan 4 siswa SMP Oikumene Kendari,. Selanjutnya, diperoleh total sampel penelitian sebanyak 114 siswa.

Instrumen yang digunakan dalam penelitian ini adalah Tes Kemampuan Literasi Matematika (TKLM) tipe PISA yang telah disusun dan dikembangkan oleh Pendidikan Matematika Realisitik Indonesia (PMRI). Butir soal TKLM dari bank soal PMRI yang diberikan kepada siswa telah dimodifikasi kebentuk uraian dan terdiri dari 20 butir. Setelah siswa menyelesaikan soal, jawaban siswa dikumpulkan, diperiksa dan dianalisis selanjutnya dideskripsikan.

Penyajian data hasil TKLM yang diperoleh, dilakukan teknik pemberian skor jawaban siswa terhadap setiap butir soal yang diteskan. Pedoman penskoran literasi matematika yang digunakan berdasarkan teknik penskoran yang diadaptasi dari QUASAR General Rubric. Setelah memberikan skor pada hasil tes literasi matematika siswa. Selanjutnya, menentukan nilai kemampuan literasi matematika siswa diperoleh dengan menggunakan rumus:

$$
X=\frac{S T}{S M I} \times 100
$$

Keterangan:

$\mathrm{X}=$ Nilai kemampuan literasi matematika siswa

ST = Skor total yang diperoleh siswa

SMI $=$ Skor maksimum ideal dari tes yang bersangkutan

$100=$ Bilangan tetap

Selanjutnya melakukan penafsiran kemampuan literasi matematika siswa SMP Swasta kelas VIII berdasarkan perhitungan dengan menggunakan rumus yang telah dipaparkan.Penafsiran ini dilakukan berdasarkan kategori Tabel 1.

Tabel 1.

Kategori Nilai Kemampuan Literasi Matematika Siswa

\begin{tabular}{|c|c|}
\hline Interval Nilai & Predikat \\
\hline$x \geq 86$ & Sangat Baik \\
\hline $76 \leq x<86$ & Baik \\
\hline $60 \leq x<76$ & Cukup \\
\hline $55 \leq x<60$ & Kurang \\
\hline
\end{tabular}




\begin{tabular}{|c|c|}
\hline$x<55$ & Kurang sekali \\
\hline
\end{tabular}

Purwanto dalam Imran (2009: 44)

Tabulasi jawaban berdasarkan aspek kemampuan literasi matematika siswa dan berdasarkan sekolah. Menganalisis dan menginterpretasikan data dengan menggunakan tabel, grafik dan diagram.

\section{Hasil}

Hasil pengolahan data Tes Kemampuan Literasi Matematika (TKLM) siswa kelas VIII SMP Swasta di kota Kendari disajikan pada Tabel

Tabel 2.

Hasil Analisis Deskriptif TKLM Siswa Setiap Sekolah

\begin{tabular}{|c|l|c|c|c|c|c|c|c|c|}
\hline No. & \multicolumn{1}{|c|}{ Nama Sekolah } & $\mathrm{N}$ & Range & Min & Maks & Sum & Mean & $\begin{array}{c}\text { Standar } \\
\text { Deviasi }\end{array}$ & Varians \\
\hline 1 & $\begin{array}{l}\text { SMP Swasta Frater } \\
\text { Kendari }\end{array}$ & 22 & 53.91 & 17.2 & 71.09 & 763.9 & 34.72 & 11.94 & 142.62 \\
\hline 2 & SMP Kartika Jaya Kendari & 39 & 36.56 & 1.56 & 38.13 & 547.8 & 14.05 & 8.16 & 66.56 \\
\hline 3 & $\begin{array}{l}\text { SMP Swasta Hasrati } \\
\text { Kendari }\end{array}$ & 4 & 6.72 & 3.13 & 9.844 & 24.84 & 6.21 & 2.78 & 7.69 \\
\hline 4 & $\begin{array}{l}\text { SMP Swasta Ilmiah } \\
\text { Kendari }\end{array}$ & 13 & 16.72 & 15.3 & 32.03 & 299.2 & 23.02 & 5.26 & 27.7 \\
\hline 5 & $\begin{array}{l}\text { SMP Integral Hidayatullah } \\
\text { Kendari }\end{array}$ & 4 & 13.28 & 16.3 & 29.53 & 93.75 & 23.44 & 5.5 & 30.29 \\
\hline 6 & SMP Satria Kendari & 9 & 17.66 & 5.16 & 22.81 & 141.6 & 15.73 & 5.87 & 34.44 \\
\hline 7 & $\begin{array}{l}\text { SMP Tahfidzul Qur`an } \\
\text { Mu`adz Bin Jabal }\end{array}$ & 19 & 39.69 & 8.59 & 48.28 & 403.9 & 21.26 & 9.27 & 85.86 \\
\hline 8 & SMP Oikumene Kendari & 4 & 30.63 & 6.56 & 37.19 & 82.19 & 20.55 & 15.89 & 252.68 \\
\hline
\end{tabular}

Berdasarkan Tabel 2. menunjukkan bahwa tingkatan nilai perolehan TKLM siswa dari rata-rata tertinggi sampai rata-rata terendah yaitu SMP Swasta Frater Kendari $(34,72)$, SMP Integral Hidayatullah Kendari $(23,44)$, Swasta Ilmiah Kendari $(23,02)$, SMP Tahfidzul Qur`an Mu`adz Bin Jabal $(21,26)$, SMP Oikumene Kendari (20,55), SMP SMP Satria Kendari $(15,73)$, SMP Kartika Jaya Kendari $(14,05)$, dan SMP Swasta Hasrati Kendari (6,21). Selanjutnya varians dari tiap sekolah menunjukkan rentang nilai yang cukup jauh dengan varians tertinggi yaitu 252,68 diperoleh SMP Oikumene Kendari dan varians terendah yaitu 7,69 diperoleh oleh SMP Swasta Hasrati Kendari.

Secara keseluruhan berdasarkan perhitungan data hasil TKLM untuk 114 sampel, diperoleh nilai terendah 3,13 dan nilai tertinggi 7,09 dan nilai rata-rata 19,87 . Hasil kategori
TKLM siswa SMP Swasta di kota Kendari diperoleh data dari banyak sampel yakni 114 siswa yang mengikuti tes, sebanyak 1 siswa mempunyai kemampuan literasi matematika yang cukup atau $0,88 \%$ dengan nilai berada pada interval $60 \leq \mathrm{x}<76$, nilai ini diperoleh siswa dari SMP Frater Kendari. Selanjutnya sisanya 113 siswa mempunyai kemampuan literasi matematika yang kurang sekali atau 99,12\% dengan nilai berada pada interval $\mathrm{x}<$ 55, nilai ini diperoleh siswa yang tersebar di tujuh SMP Swasta di kota Kendari yang termasuk SMP Tahfidzul Qur`an Mu`adz Bin Jabal, SMP Oikumene Kendari, SMP Integral Hidayatullah Kendari, SMP Swasta Ilmiah Kendari, SMP Satria Kendari, SMP Kartika Jaya Kendari, dan SMP Swasta Hasrati Kendari. Sedangkan siswa yang memiliki kemampuan literasi matematika yang sangat baik, baik maupun kurang tidak dimiliki oleh siswa di 
delapan SMP Swasta di kota Kendari ini atau $0 \%$. Dari data tersebut, maka dapat disimpulkan bahwa siswa kelas VIII SMP Swasta di kota Kendari cenderung memiliki kemampuan literasi matematika yang termasuk kategori kurang sekali.Perolehan ini dipengaruhi oleh karakter butir soal literasi matematika yang terdiri dari level, domain konten dan konteks.
Kemampuan matematika siswa dalam PISA dibagi menjadi enam level (tingkatan). Semakin tinggi tingkatan level soal tes literasi matematika menunjukkan masalah yang semakin kompleks. Berikut analisis hasil TKLM siswa kelas VIII SMP Swasta di kota Kendari pada setiap level literasi matematika disajikan pada Gambar 1.

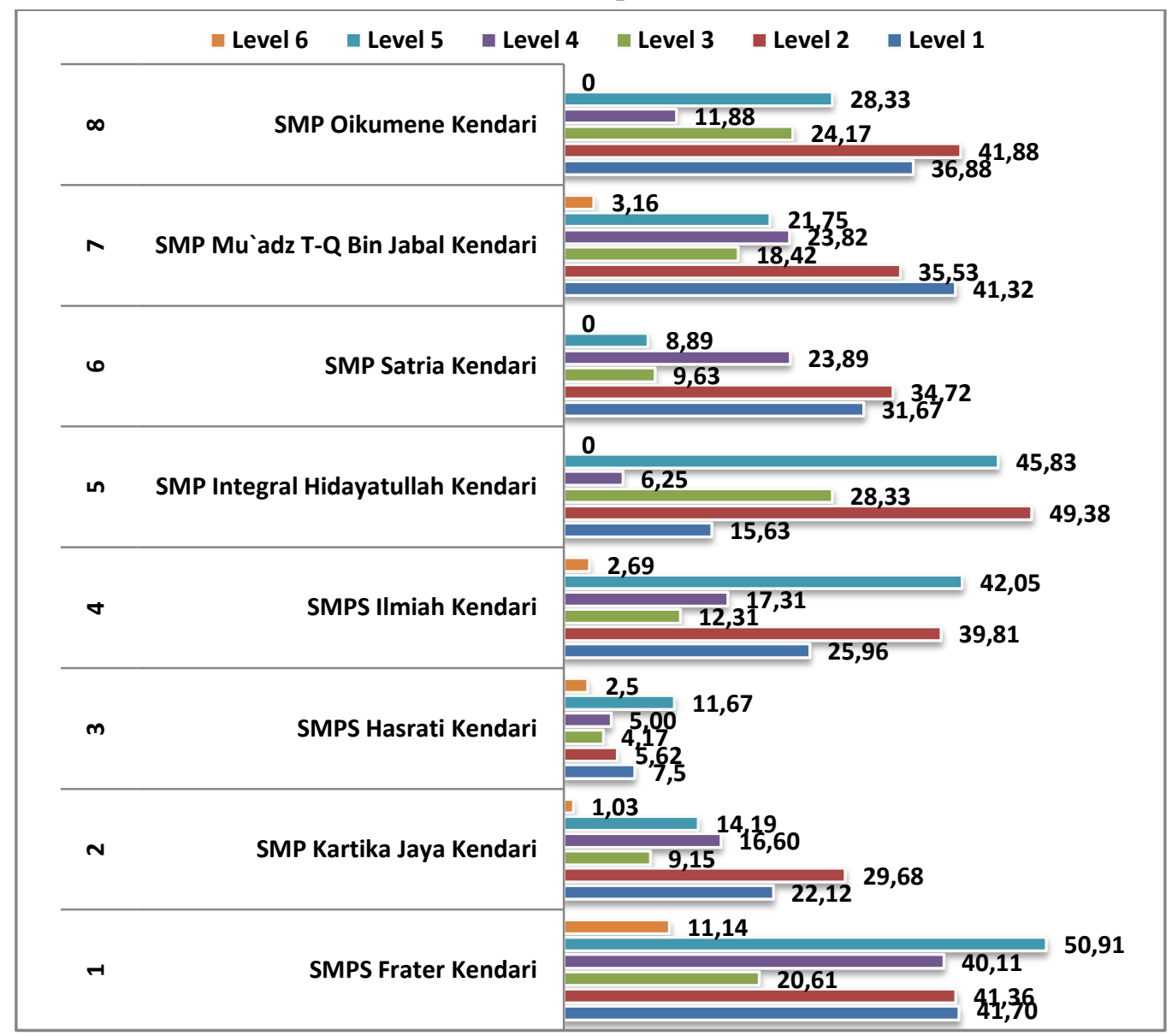

\section{Gambar 1. Capaian Rata-Rata Level Kemampuan Literasi Matematika Siswa kelas VIII SMP Swasta Kota Kendari Berdasarkan Sekolah}

Gambar 1. menunjukkan bahwa capaian rata-rata level kemampuan literasi matematika siswa berdasarkan sekolah mulai dari rata-rata level tingkatan tertinggi sampai tingkatan terendah untuk SMP Swasta Frater Kendari berturut-turut yaitu level 5, level 1, level 2, level 4 , level 3 dan level 6 dengan nilai 50,91; 41,70; 41,36; 40,11; 20,61 dan 11,14. Level tingkatan tertinggi sampai tingkatan terendah untuk SMP Kartika Jaya Kendari berturut-turut yaitu level 2, level 1 , level 4, level 5, level 3 dan level 6 dengan nilai 29,$68 ; 22,12 ; 16,60 ; 14,19 ; 9,15$ dan 1,03. Level tingkatan tertinggi sampai tingkatan terendah untuk SMPS Hasrati Kendari berturut-turut yaitu level 5, level 1 , level 4 , level
2, level 3 dan level 6 dengan nilai 11,67; 7,5; 5,$62 ; 5,00 ; 4,17$ dan 2,5. Level tingkatan tertinggi sampai tingkatan terendah untuk SMPS Ilmiah Kendari berturut-turut yaitu level 5, level 2 , level 1 , level 4 , level 3 dan level 6 dengan nilai 42,$05 ; 39,81 ; 25,96 ; 17,31 ; 12,31$ dan 2,69 . Level tingkatan tertinggi sampai tingkatan terendah untuk SMP Integral Hidayatullah Kendari berturut-turut yaitu level 2, level 5, level 3, level 4, level 1 dan level 6 dengan nilai 49,$38 ; 45,83 ; 28,33 ; 15,63 ; 6,25$ dan 0 . Level tingkatan tertinggi sampai tingkatan terendah untuk SMP Satria Kendari berturut-turut yaitu level 2, level 1, level 4, level 3, level 5 dan level 6 dengan nilai 34,$72 ; 31,67 ; 23,89 ; 9,63 ; 8,89$ 
dan 0. Level tingkatan tertinggi sampai tingkatan terendah untuk SMP Mu`adz T-Q Bin Jabal Kendari berturut-turut yaitu level 1 , level 2, level 4, level 5, level 3 dan level 6 dengan nilai 41,$32 ; 35,53 ; 23,82 ; 21,75 ; 18,42$ dan 3,16 . Selanjutnya level tingkatan tertinggi sampai tingkatan terendah untuk SMP Oikumene
Kendari berturut-turut yaitu level 2, level 1, level 5, level 3, level 4 dan level 6 dengan nilai 41,$88 ; 36,88 ; 28,33 ; 24,17 ; 11,88$ dan 0 .

$$
\text { Sedangkan capaian rata-rata }
$$
kemampuan literasi matematika siswa kelas VIII SMP swasta kota Kendari berdasarkan level disajikan pada Gambar 2.

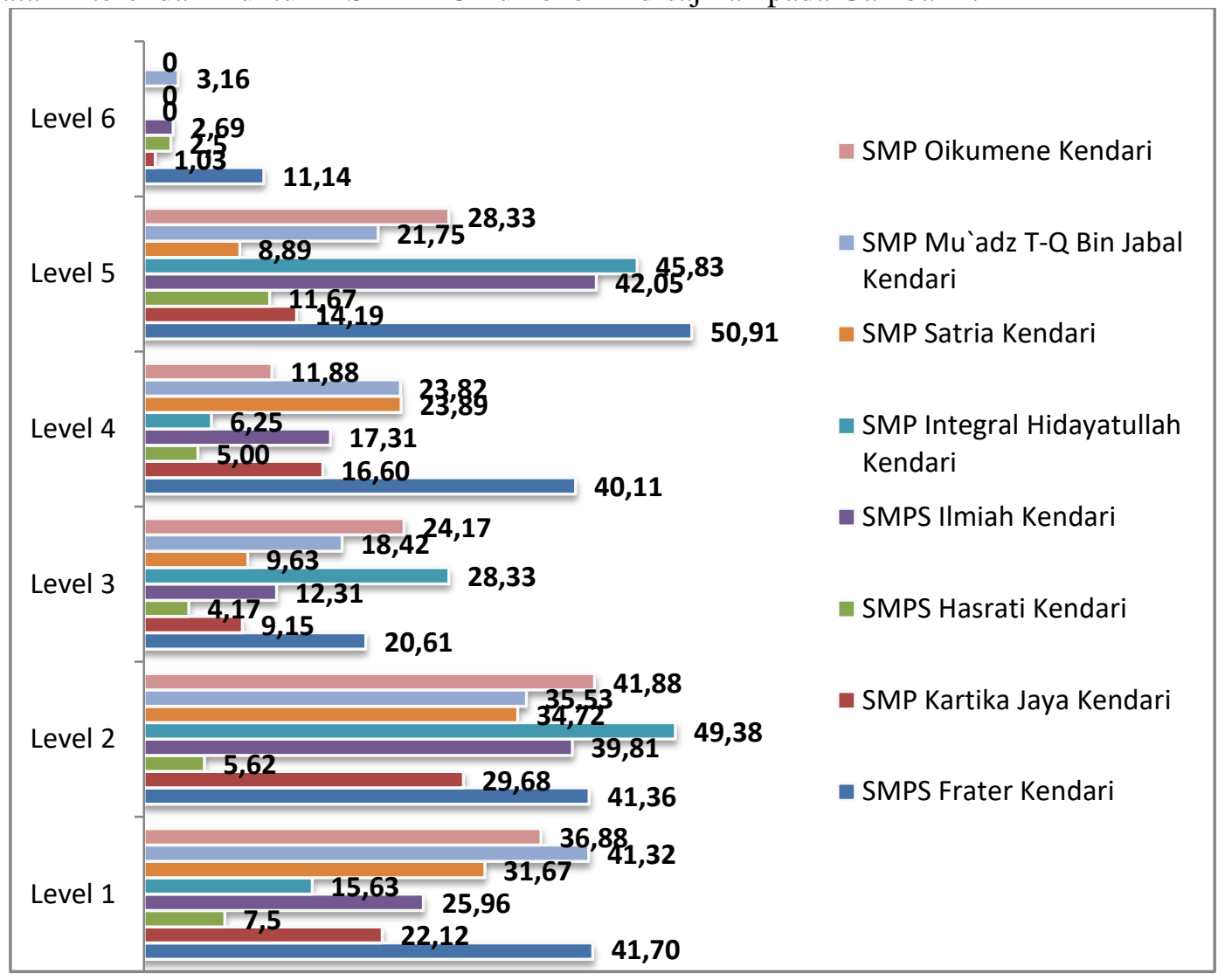

\section{Gambar 2. Capaian Rata-Rata Kemampuan Literasi Matematika Siswa Kelas VIII SMP Swasta Kota Kendari Berdasarkan Level}

Gambar 2. menunjukkan bahwa capaian rataratakemampuan literasi matematika siswa kelas VIII SMP Swasta kota Kendari berdasarkan level dengan rata-rata tingkatan tertinggi sampai tingkatan terendah untuk level 1 berturut-turut yaitu SMPS Frater Kendari, SMP Mu`adz T-Q Bin Jabal Kendari, SMP Oikumene Kendari, SMP Satria Kendari, SMPS Ilmiah Kendari, SMP Kartika Jaya Kendari, SMP Integral Hidayatullah Kendari dan SMPS Hasrati Kendari yakni dengan nilai berturut-turut 41,70 ; 41,$32 ; 31,88 ; 31,67 ; 25,96 ; 22,12 ; 15,63$ dan 7,5. Tingkatan tertinggi sampai tingkatan terendah untuk level 2 berturut-turut yaitu SMP Integral Hidayatullah Kendari, SMP Oikumene Kendari SMPS Frater Kendari, SMPS Ilmiah Kendari, SMP Mu`adz T-Q Bin Jabal Kendari, SMP
Satria Kendari, SMP Kartika Jaya Kendari dan SMPS Hasrati Kendari yakni dengan nilai berturut-turut 49,38; 41,88; 41,36; 39,81; 35,53; 34,$72 ; 29,68$ dan 5,63 . Tingkatan tertinggi sampai tingkatan terendah untuk level 3 berturut-turut yaitu SMP Integral Hidayatullah Kendari, SMP Oikumene Kendari SMPS Frater Kendari, SMP Mu`adz T-Q Bin Jabal Kendari, SMPS Ilmiah Kendari, SMP Satria Kendari, SMP Kartika Jaya Kendari dan SMPS Hasrati Kendari yakni dengan nilai berturut-turut 28,33 ; 24,$17 ; 20,61 ; 18,42 ; 12,31 ; 9,63 ; 9,15$ dan 4,17 . Tingkatan tertinggi sampai tingkatan terendah untuk level 4 berturut-turut yaitu SMPS Frater Kendari, SMP Satria Kendari, SMP Mu adz T-Q Bin Jabal Kendari, SMPS Ilmiah Kendari, SMP Kartika Jaya Kendari, SMP Oikumene Kendari, 
SMP Integral Hidayatullah Kendari dan SMPS Hasrati Kendari yakni dengan nilai berturutturut 40,$11 ; 23,89 ; 23,82 ; 17,31 ; 16,6 ; 11,88$; 6,25 dan 5. Tingkatan tertinggi sampai tingkatan terendah untuk level 5 berturut-turut yaitu SMPS Frater Kendari, SMP Integral Hidayatullah Kendari, SMPS Ilmiah Kendari, SMP Oikumene Kendari SMP Mu`adz T-Q Bin Jabal Kendari, SMP Kartika Jaya Kendari, SMPS Hasrati Kendari dan SMP Satria Kendari yakni dengan nilai berturut-turut 50,$91 ; 45,83$; 42,$05 ; 28,33 ; 21,75 ; 14,19 ; 11,67$ dan 8,89 . Selanjutnya tingkatan tertinggi sampai tingkatan terendah untuk level 6 berturut-turut yaitu SMPS Frater Kendari, SMP Mu`adz T-Q Bin Jabal Kendari, SMPS Ilmiah Kendari, SMPS Hasrati Kendari, SMP Kartika Jaya Kendari, SMP Integral Hidayatullah Kendari, SMP
Oikumene Kendari, dan SMP Satria Kendari yakni dengan nilai berturut-turut 11,$14 ; 3,16$; 2,$69 ; 2,5 ; 1,03$; dan nilai rata-rata tiga SMP Swasta terakhir yaitu 0 .

Sesuai desain tes internasional PISA, butir soal literasi matematika dibagi menjadi empat domain berdasarkan konten (fenoma) yang sesuai dengan materi matematika pada kurukulum yaitu change and relationship mencakup materi aljabar, fungsi dan perbandingan, shape and space mencakup materi geometri, quantity mencakup materi pola bilangan, dan uncertainty and data mencakup materi yakni statistika dan peluang. Berikut adalah nilai rata-rata kemampuan literasi matematika siswa SMP Swasta di kota Kendari untuk setiap konten.

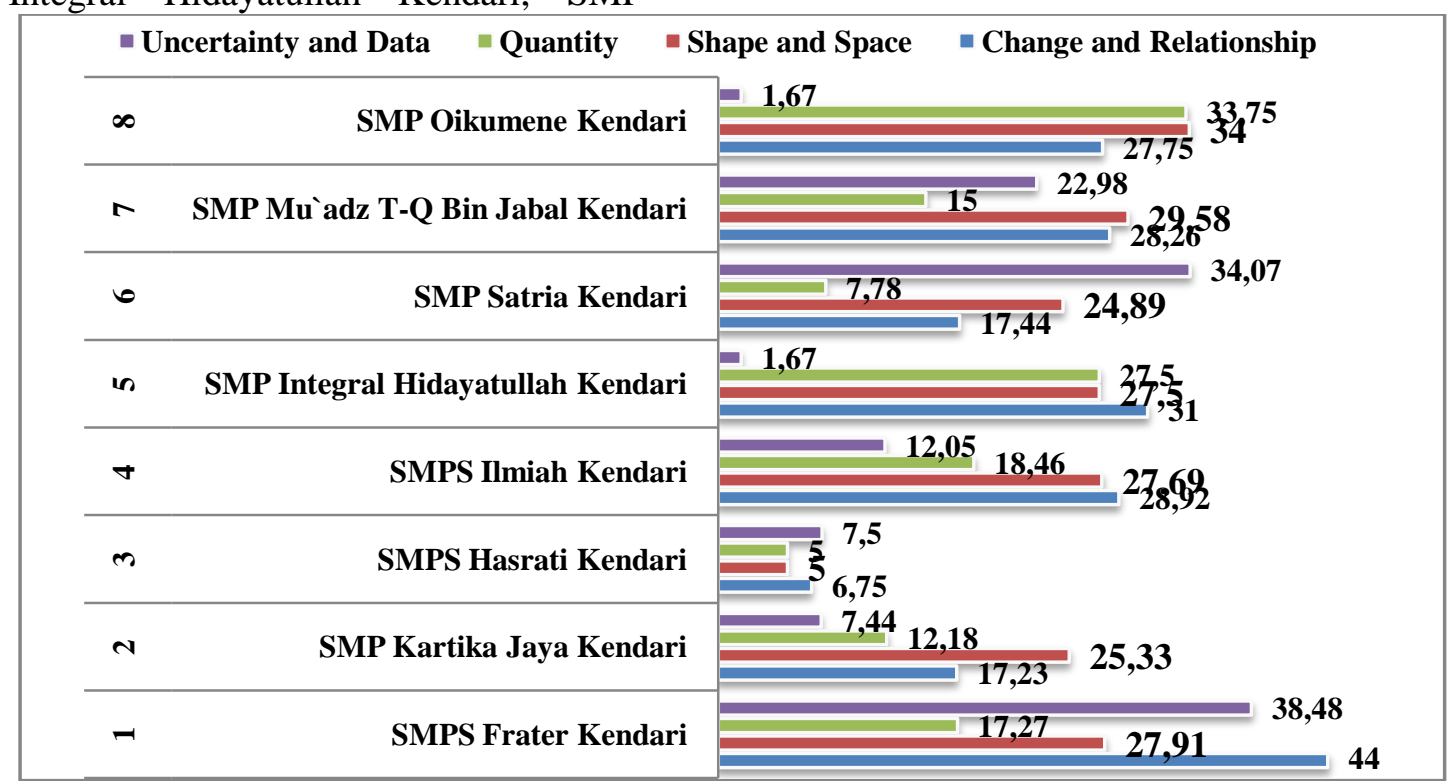

\section{Gambar 3. Capaian Rata-Rata Konten Literasi Matematika Siswa Kelas VIII SMP Swasta Kota Kendari Berdasarkan Sekolah}

Gambar 3. menunjukkan bahwa capaian ratarata konten literasi matematika siswa kelas VIII SMP Swasta kota Kendari berdasarkan sekolah mulai dari rata-rata konten tingkatan tertinggi sampai tingkatan terendah untuk SMP Swasta Frater Kendari berturut-turut yaitu change and relationship, uncertainty and data, shape and space dan quantity dengan nilai 44; 38,48; 27,91; dan 17,27. Konten tingkatan tertinggi sampai tingkatan terendah untuk SMP Kartika Jaya Kendari berturut-turut yaitu shape and space, change and relationship, quantity dan uncertainty and data dengan nilai 25,33; 17,23; 12,18; dan 7,44. Konten tingkatan tertinggi sampai tingkatan terendah untuk SMPS Hasrati Kendari berturut-turut yaitu uncertainty and data, change and relationship, shape and space dan quantity dengan nilai 7,$5 ; 6,75 ; 5$ dan 5 . Konten tingkatan tertinggi sampai tingkatan terendah untuk SMPS Ilmiah Kendari berturutturut yaitu change and relationship, shape and space, quantity dan level uncertainty and data dengan nilai 28,92; 27,69; 18,46 dan 12,05. Konten tingkatan tertinggi sampai tingkatan terendah untuk SMP Integral Hidayatullah Kendari berturut-turut yaitu change and relationship, shape and space, quantity dan uncertainty and data dengan nilai 31; 27,5; 27,4 
dan 1,67. Konten tingkatan tertinggi sampai tingkatan terendah untuk SMP Satria Kendari berturut-turut yaitu uncertainty and data, shape and space, change and relationship dan quantity dengan nilai 34,07; 24,89; 17,44 dan 7,78. Konten tingkatan tertinggi sampai tingkatan terendah untuk SMP Mu'adz T-Q Bin Jabal Kendari berturut-turut yaitu shape and space, change and relationship, uncertainty and data dan quantity dengan nilai 29,58;28,26;22,98 dan 15. Selanjutnya Konten tingkatan tertinggi sampai tingkatan terendah untuk SMP Oikumene Kendari berturut-turut yaitu shape and space, quantity, change and relationship dan uncertainty and data dengan nilai $34 ; 33,75$; 27,75 dan 1,67.

Sedangkan capaian rata-rata kemampuan literasi matematika siswa kelas VIII SMP Swasta kota Kendari berdasarkan konten disajikan pada Gambar 4.

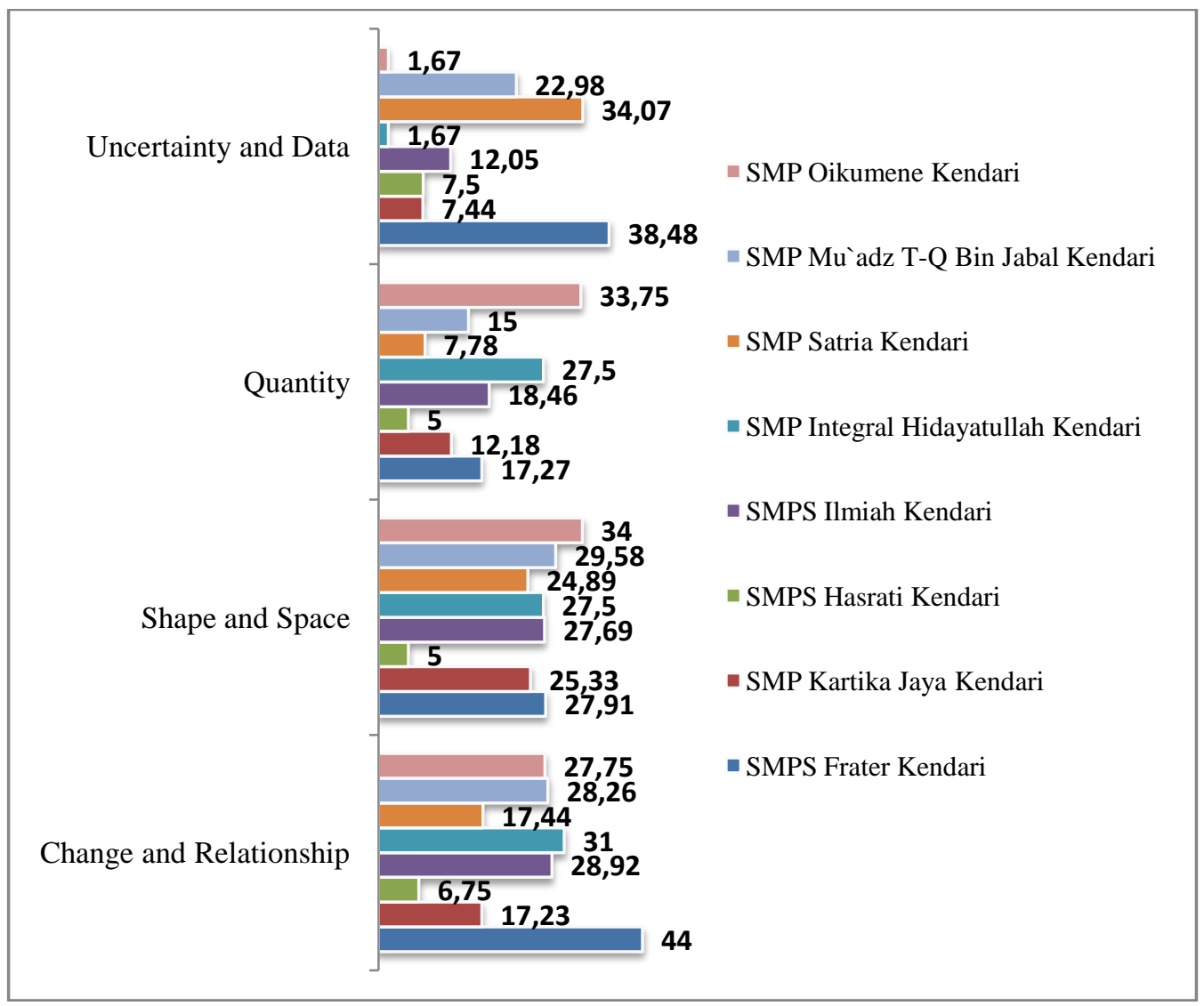

\section{Gambar 4. Capaian Rata-Rata Kemampuan Literasi Matematika Siswa Kelas VIII SMP Swasta Kota Kendari Berdasarkan Domain Konten}

Gambar 4. menunjukkan bahwa capaian rataratakemampuan literasi matematika siswa kelas VIII SMP Swasta kota Kendari berdasarkan domain konten dengan rata-rata tingkatan tertinggi sampai tingkatan terendah untuk konten change and relationship berturut-turut yaitu SMPS Frater Kendari, SMP Integral Hidayatullah Kendari, SMPS Ilmiah Kendari, SMP Mu`adz T-Q Bin Jabal Kendari, SMP Oikumene Kendari, SMP Satria Kendari, SMP Kartika Jaya Kendari dan SMPS Hasrati Kendari yakni dengan nilai berturut-turut $44 ; 31$;
28,$26 ; 28,92 ; 27,75 ; 17,44 ; 17,23$ dan 6,75 . Tingkatan tertinggi sampai tingkatan terendah untuk konten shape and space berturut-turut yaitu SMP Oikumene Kendari, SMP Mu`adz TQ Bin Jabal Kendari, SMPS Frater Kendari, SMPS Ilmiah Kendari, SMP Integral Hidayatullah Kendari, SMP Kartika Jaya Kendari, SMP Satria Kendari dan SMPS Hasrati Kendari yakni dengan nilai berturut-turut 34; 29,$58 ; 27,91 ; 27,69 ; 27,5 ; 25,33 ; 17,44$ dan 5 . Tingkatan tertinggi sampai tingkatan terendah untuk konten quantity berturut-turut yaitu SMP 
Oikumene Kendari, SMP Integral Hidayatullah Kendari, SMPS Ilmiah Kendari, SMPS Frater Kendari, SMP Mu adz T-Q Bin Jabal Kendari, SMP Kartika Jaya Kendari, SMP Satria Kendari dan SMPS Hasrati Kendari yakni dengan nilai berturut-turut 33,$75 ; 27,5 ; 18,46 ; 17,27 ; 15$; 12,18; 7,78 dan 5, selanjutnya Tingkatan tertinggi sampai tingkatan terendah untuk konten uncertainty and data berturut-turut yaitu SMPS Frater Kendari, SMP Satria Kendari, SMP Mu`adz T-Q Bin Jabal Kendari, SMPS Ilmiah Kendari, SMPS Hasrati Kendari, SMP Kartika Jaya Kendari, SMP Oikumene Kendari, SMP Integral Hidayatullah Kendari yakni dengan nilai berturut-turut 38,$48 ; 34,07 ; 22,98$; 12,$05 ; 7,5 ; 7,44 ; 1,67$ dan 1,67.

Berdasarkan konteks (situasi), butir soal literasi matematika terdiri atas empat domain yakni personal berhubungan dengan kegiatan pribadi dalam kehidupan sehari-hari, occupational berhubungan dengan kehidupan di lingkungna kerja, societal berhubungan dengan kehidupan di lingkungan masyarakatdan scientific berhubungan dengan kegiatan ilmiah. Berikut adalah nilai rata-rata kemampuan literasi matematika Siswa Kelas VIII SMP Swasta di kota Kendari untuk tiap konteks.

\begin{tabular}{|c|c|c|}
\hline & - Scientific & - Occuptional $\quad$ Personal \\
\hline$\infty$ & SMP Oikumene Kendari & $\begin{array}{lll}20,5 & 20 & 35,5\end{array}$ \\
\hline n & SMP Mu`adz T-Q Bin Jabal Kendari & $\begin{aligned} 22,84,79 \\
23,79\end{aligned}$ \\
\hline 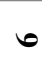 & SMP Satria Kendari & 30,63 \\
\hline $\ln$ & SMP Integral Hidavatullah Kendari & \begin{tabular}{|l|l|}
16 & 34 \\
\end{tabular} \\
\hline & & \begin{tabular}{|r|}
22,5 \\
\end{tabular} 29 \\
\hline$\nabla$ & SMPS Ilmiah Kendari & $28,15^{33,54}$ \\
\hline$m$ & SMPS Hasrati Kendari & $\begin{array}{r}7 \\
5,5,5 \\
\end{array}$ \\
\hline N & SMP Kartika Jaya Kendari & $\begin{array}{ll}5,03 & 16,5 \\
\end{array}$ \\
\hline- & SMPS Frater Kendari & $28,36^{3,45} 40,64,45$ \\
\hline
\end{tabular}

\section{Gambar 5. Capaian Rata-Rata Konteks Literasi Matematika Siswa Kelas VIII SMP Swasta Kota Kendari Berdasarkan Sekolah}

Gambar 5. menunjukkan bahwa capaian ratarata konten literasi matematika siswa kelas VIII SMP Swasta kota Kendari berdasarkan sekolah mulai dari rata-rata konteks tingkatan tertinggi sampai tingkatan terendah untuk SMP Swasta Frater Kendari berturut-turut yaitu personal, occuptional, scientific dan societal dengan nilai 44,$45 ; \quad 40,64 ; \quad 32,45 ;$ dan 28,36. Konteks tingkatan tertinggi sampai tingkatan terendah untuk SMP Kartika Jaya Kendari berturut-turut yaitu personal, scientific, societal dan occuptional dengan nilai 29,$90 ; 17,69 ; 16,51$ dan 5,03. Konteks tingkatan tertinggi sampai tingkatan terendah untuk SMPS Hasrati Kendari berturut-turut yaitu occuptional, scientific, personal dan societal dengan nilai 7,5; 7; 5,5 dan 5. Konteks tingkatan tertinggi sampai tingkatan terendah untuk SMPS Ilmiah Kendari berturut-turut yaitu personal, occuptional, scientific dan societal dengan nilai 48,92; 46,62; 33,54 dan 28,15 . Konteks tingkatan tertinggi sampai tingkatan terendah untuk SMP Integral Hidayatullah Kendari berturut-turut yaitu societal, personal, ocutional dan scientific dengan nilai $34 ; 29 ; 22,5$ dan 16 . Konteks tingkatan tertinggi sampai tingkatan terendah untuk SMP Satria Kendari berturut-turut yaitu personal, occuptional, scientific dan societal dengan nilai 48,67; 44; 33,33 dan 30,67. Konteks tingkatan tertinggi sampai tingkatan terendah untuk SMP Mu adz T-Q Bin Jabal Kendari berturut-turut yaitu personal, societal, occupational dan scientific dengan nilai 35,16; 24,$11 ; 23,79$ dan 22,84. Selanjutnya Konteks tingkatan tertinggi sampai tingkatan terendah untuk SMP Oikumene Kendari berturut-turut yaitu personal, scientific, societal dan occuptional dengan nilai 36; 35,5; 20 dan 12,5. 
Sedangkan capaian rata-rata SMP Swasta kota Kendari berdasarkan konteks kemampuan literasi matematika siswa kelas VIII disajikan pada Gambar 6.

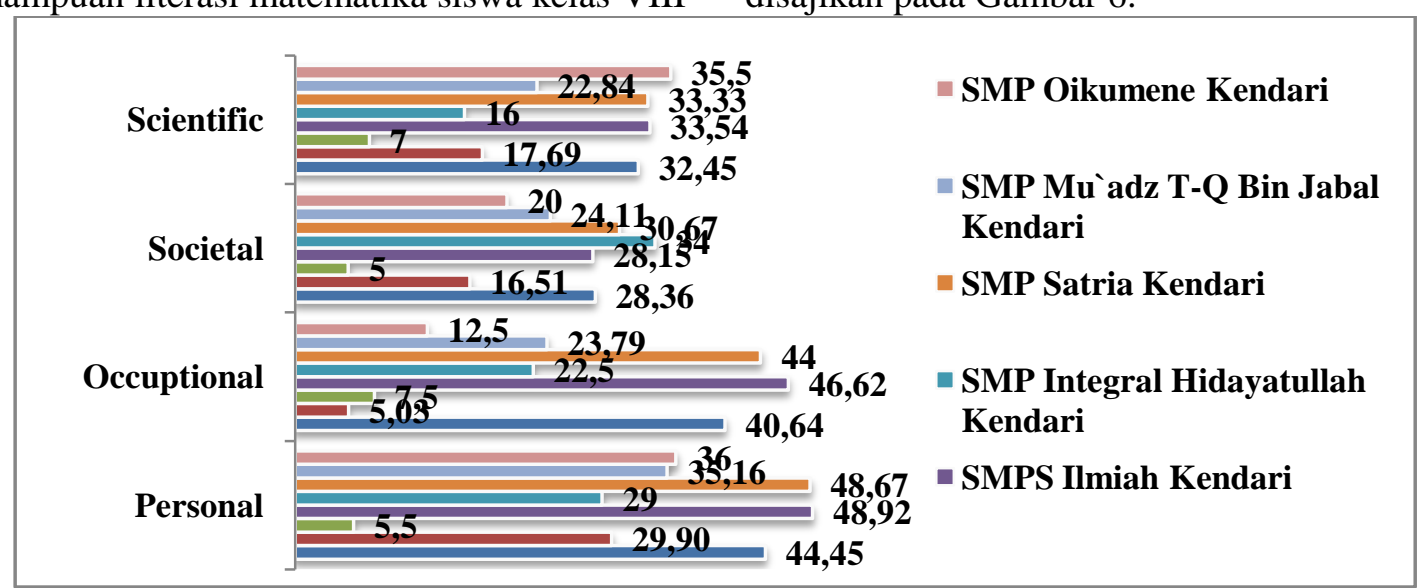

\section{Gambar 6. Capaian Rata-Rata Kemampuan Literasi Matematika Siswa Kelas VIII SMP Swasta Kota Kendari Berdasarkan Domain Konteks}

Gambar 6. menunjukkan bahwa capaian rataratakemampuan literasi matematika siswa kelas VIII SMP Swasta kota Kendari berdasarkan domain konteks dengan rata-rata tingkatan tertinggi sampai tingkatan terendah untuk konteks personal berturut-turut yaitu SMPS Ilmiah Kendari, SMP Satria Kendari, SMPS Frater Kendari, SMP Oikumene Kendari, SMP Mu`adz T-Q Bin Jabal Kendari, SMP Kartika Jaya Kendari, SMP Integral Hidayatullah Kendari, dan SMPS Hasrati Kendari yakni dengan nilai berturut-turut 48,$92 ; 48,67 ; 44,45$; $36 ; 35,16 ; 29,9 ; 29$ dan 5,5. Tingkatan tertinggi sampai tingkatan terendah untuk konteks occuptional berturut-turut yaitu SMPS Ilmiah Kendari, SMP Satria Kendari, SMPS Frater Kendari, SMP Mu`adz T-Q Bin Jabal Kendari, SMP Integral Hidayatullah Kendari, SMP Oikumene Kendari, SMPS Hasrati Kendari dan SMP Kartika Jaya Kendari yakni dengan nilai berturut-turut 46,$62 ; 44 ; 40,64 ; 23,79 ; 22,5$; 12,$5 ; 7,5$ dan 5,03 . Tingkatan tertinggi sampai tingkatan terendah untuk konteks societal berturut-turut yaitu SMP Integral Hidayatullah Kendari,SMP Satria Kendari, SMPS Frater Kendari, SMPS Ilmiah Kendari, SMP Mu`adz T-Q Bin Jabal Kendari, SMP Oikumene Kendari, SMP Kartika Jaya Kendari dan SMPS Hasrati Kendari yakni dengan nilai berturutturut $34 ; 30,67 ; 28,36 ; 28,15 ; 24,11 ; 20 ; 16,51$ dan 5, selanjutnya Tingkatan tertinggi sampai tingkatan terendah untuk konteks scientific berturut-turut yaitu SMP Oikumene Kendari, SMPS Ilmiah Kendari, SMP Satria Kendari,
SMPS Frater Kendari, SMP Mu`adz T-Q Bin Jabal Kendari, SMP Kartika Jaya Kendari, SMP Integral Hidayatullah Kendari dan SMPS Hasrati Kendari yakni dengan nilai berturutturut 35,$5 ; 33,54 ; 33,33 ; 32,45 ; 22,84 ; 17,69 ; 16$ dan 7.

\section{Pembahasan}

Uraian data secara deskriptif menunujukkan bahwa kemampuan literasi matematika siswa kelas VIII SMP Swasta di Kota Kendari dengan sampel penelitian berjumlah 114 orang termasuk kategori kurang sekali. Hal ini dibuktikan dengan perolehan nilai rata-rata 114 siswa hanya sebesar 19,87. Perolehan nilai yang rendah ini salah satunya dipengaruhi oleh karakteristik butir soal literasi matematika yang terdiri dari level literasi matematika, domain konten dan konteks. Hal ini sejalan dengan pendapat OECD (2009: 21-36), untuk menyelesaikan soal litrasi matematika, siswa terlebih dahulu perlu mengidentifikasi komponen mayor yang terdiri dari level literasi matematika, domain konten dan konteks, hal ini dimaksudkan untuk mempermudah siswa dalam menyelesaikan soal literasi matematika.

Telah dijelaskan sebelumnya, bahwa soal kajian literasi matematika disusun berdasarkan level, di mana level tersebut memiliki karakteristik yang beragam, mulai dari level terendah yang hanya sekedar mengetahui hingga soal dengan level tertinggi untuk mengukur kemampuan siswa merefleksi. Hasil 
tes siswa menunjukkan bahwa nilai rata-rata terendah terdapat pada soal level $6(3,42)$, yaitu soal dengan level kognitif yang kompleks. Soal yang mengukur kemampuan berpikir tingkat tinggi (higher order thinking skills) belum mampu dikuasai siswa dengan baik. Sedangkan nilai rata-rata level $2(34,74)$ merupakan ratarata tertinggi. Secara empirik siswa-siswa lebih rendah proporsi yang menjawab benar pada level $1,3,4,5$ dengan nilai rata-rata berturutturut 30,$07 ; 14,33 ; 22,06 ; 26,81$ dibanding level 2. Data nilai rata-rata ini juga menunujukkan bahwa pada setiap level literasi matematika kemampuan siswa termasuk kategori kurang sekali sedangkan sebaran kemampuan literasi matematika siswa berdasarkan level, kemampuan siswa cenderung homogen pada level 6, hal ini dibuktikan dengan nilai standar deviasi pada level 6 sebesar 9,98 lebih rendah dari level lain.

Sesuai desain tes internasional PISA butir soal literasi matematika dibagi menjadi empat domain berdasarkan konten yaituchange and relationship, shape and space, quantity, dan uncertainty and data.Fungsi aritmatika dan aljabar terangkum dalam change and relationship, geometri dan pengukuran terangkum dalam shape and space, pola bilangan terdapat pada quantity, sedangkan pada uncertainty and data berhubungan dengan statistika dan peluang.

Berdasarkan konten yang diujikan, ratarata domain terbaik yang di raih siswa adalah shape and space $(26,44)$ hal ini menunjukkan bahwa shape and space merupakan konten yang paling mudah dibandingkan konten matematika lainnya bagi siswa sampel penelitian yang tersebar di delapan SMP Swasta di kota Kendari. Pada konten shape and space mengukur kemampuan siswa dalam pemahaman perspektif (dalam gambar), membuat dan membaca peta, mentransformasikan bentuk dengan dan tanpa teknologi, menginterpretasikan dimensi tiga dari berbagai perspektif dan mengonstruk representasi bentuk. Sedangkan rata-rata domain terendah yang diraih siswa adalah quantity $(15,04)$, konten ini berkaitan dengan hubungan bilangan dan pola bilangan dalam kehidupan sehari-hari, seperti menghitung dan mengukur benda tertentu. Termasuk ke dalam konten kuantitas ini adalah kemampuan bernalar secara kuantitatif, mempresentasikan sesuatu dalam angka, memahami langkah-langkah matematika, berhitung di luar kepala (mental calculation), dan melakukan penaksiran (estimation).sedangkan domain konten lainnya yaitu change and relationship $(26,07)$ dan uncertainty and data $(18,25)$ berada diantara konten shape and space dan quantity.Lemahnya literasi matematika pada konten change and relationship, quantity dan uncertainty and data menunjukkan bahwa siswa ternyata kurang mampu memahami materi ajar terkait dengan fungsi aritmatik, aljabar, konsep bilangan, statistika dan peluang.

Data nilai rata-rata pada setiap konten literasi matematika termasuk kategori kurang sekali. Sedangkan sebaran kemampuan literasi matematika siswa berdasarkan konten, kemampuan siswa cenderung homogen pada konten Shape and Space, hal ini dibuktikan dengan nilai standar deviasi pada konten Shape and Space sebesar 13,39 lebih rendah dari konten lain.

Berdasarkan konteks, butir soal literasi matematika terdiri atas empat domain, yakni, personal, occupational, societal dan scientific.Konteks personal mencakup permasalahan yang berkaitan dengan kehidupan sehari-hari.Konteks occupational terkait dengan dunia kerja atau profesi.Konteks societal terkait dengan lingkungan masyarakat sedangkan konteks scientific berkaitan dengan dunia akademis.Contoh konteks scientific misalnya soal yang menghitung volume tabung (soal nomor 16).Contoh konteks societal mengangkat soal wilayah air bumi sebagai stimulus (soal nomor 20).Konteks occuptional dicontohkan dengan stimulus yang berisi tendangan pinalti pesepak bola (soal nomor 3), sedangkan stimulus konteks personal mengangkat contoh soal dengan anda diminta merancang ukuran koin (soal nomor 15).

Secara keseluruhan, data rata-rata nilai tertinggi terdapat pada literasi matematika konteks personal dengan nilai 36,18. Rata-rata nilai yang sedikit lebih rendah adalah pada soal konteks occupational $(25,37)$ dan scientific $(25,29)$, sedangkan konten societal adalah nilai rata-rata terendah yang dicapai siswa $(21,73)$. Dari data nilai rata-rata ini, menunujukkan bahwa nilai rata-rata pada setiap konteks literasi matematika termasuk kategori kurang sekali. Sedangkan sebaran kemampuan literasi matematika siswa berdasarkan konteks, 
kemampuan siswa cenderung homogen pada konteks personal, hal ini dibuktikan dengan nilai standar deviasi pada konteks personal sebesar 15,79 lebih rendah dari konteks lain.

Penjelasan kerangka PISA tahun 2012 disebutkan bahwa societal berhubungan dengan komunitas baik lokal, nasional atau global di mana individu menjalani kehidupannya.Rendahnya capaian literasi siswa pada konteks societal dimungkinkan siswa kurang memahami soal yang berhubungan dunia sosial, dimana mereka harus menginterpretasikan kembali soal tersebut ke dalam konteks matematika agar dapat di selesaikan. Tingkat interpretasi butir soal matematika konteks societal kiranya lebih tinggi dari pada domain lain (personal, occupational, scientific) karena pada konteks ini mereka harus menghubungkan dunia sosial dengan dunia matematika. Sesuai dengan kerangka PISA 2012 butir soal konteks personal mengukur literasi matematika siswa terkait masalah dan tantangan yang dihadapi individu.Pada konteks occupational, butir soal berhubungan dengan dunia kerja, sedangkan pada konteks scientific butir soal berhubungan dengan penggunaan matematika dalam ilmu pengetahuan dan teknologi.

\section{Simpulan dan Saran}

\section{Simpulan}

Berdasarkan hasil analisis dan pembahasan, maka peneliti menyimpulkan terkait kemampuan literasi matematika siswa sebagai berikut.

1. Kemampuan literasi matematika siswa kelas VIII SMP Swasta di kota Kendari secara umum termasuk kategori kurang sekali, dibuktikan dengan rata-rata nilai perolehan siswa di delapan sekolah ini hanya mencapai 19,87 , selanjutnya bila dikaji berdasarkan level, kemampuan siswa unggul di level 2 dan kurang pada level 6. Berdasarkan domain konten, shape and space merupakan konten yang paling mudah dipahami siswa, dibanding konten change and relationship, uncertainty and data, dan quantity. Berdasarkan domain konteks, societal merupakan konteks yang paling rendah dikuasai siswa, sedangkan yang paling mudah dikuasai siswa adalah konteks personal.
2. Kemampuan literasi matematika siswa kelas VIII dari masing-masing SMP Swasta di kota kendari yang terdiri dari siswa SMP Swasta Frater Kendari mempunyai kemampuan literasi matematika termasuk kategori kurang sekali, dibuktikan dengan rara-rata nilai perolehan siswa hanya mencapai 34,72 (skala 100), jika dikaji berdasarkan level, siswa unggul pada level 5 dan kurang pada level 6, berdasarkan domain konten, siswa lebih memahami konten change and relationship dibanding konten lainnya (shape and space, uncertainty and data, dan quantity), berdasarkan domain konteks, siswa lebih memahami konteks personal dibandingkan konteks lainnya (occupational, scientific, dan societal). Siswa SMP Kartika Jaya Kendari mempunyai kemampuan literasi matematika termasuk kategori kurang sekali, dibuktikan dengan rara-rata nilai perolehan siswa hanya mencapai 14,05 (skala 100), jika dikaji berdasarkan level, siswa unggul pada level 2 dan kurang pada level 6, berdasarkan domain konten, siswa lebih memahami konten shape and space dibanding konten lainnya (change and relationship, uncertainty and data, dan quantity), berdasarkan domain konteks, siswa lebih memahami konteks personal dibandingkan konteks lainnya (occupational, scientific, dan societal). Siswa SMP Swasta Hasrati Kendari mempunyai kemampuan literasi matematika termasuk kategori kurang sekali, dibuktikan dengan rara-rata nilai perolehan siswa hanya mencapai 6,21 (skala 100), jika dikaji berdasarkan level, siswa unggul pada level 5 dan kurang pada level 6, berdasarkan domain konten siswa lebih memahami konten shape and space dibanding konten lainnya (change and relationship, uncertainty and data, dan quantity), berdasarkan domain konteks, siswa lebih memahami konteks occuptional dibandingkan konteks lainnya (personal, scientific, dan societal).

\section{Saran}

Berdasarkan kesimpulan yang telah diuraikan, saran yang dapat diberikan adalah sebagai berikut. 
1. Kelemahan dari penelitian ini adalah sampel penelitian belum mempelajari semua materi pada tes yang diberikan seperti materi bangun ruang sisi datar dan peluang yang akan dipelajari di semester 2. Sehingga disarankan pada peneliti selanjutnya untuk memilih sampel penelitian di kelas 3 .

2. Guru dapat melatih level kognitif siswa dengan mengerjakan soal-soal literasi matematika baik dari level terendah yang hanya sekedar mengetahui hingga soal dengan level tertinggi untuk mengukur kemampuan siswa merefleksi.

\section{Daftar Pustaka}

Hamidy, Anwaril. (2016). Kemampuan Matematika Siswa SMP Kalimantan Timur dalam Menyelesaikan Soal Model Pisa dan Timss.Tesis UNY: tidak diterbitkan.

Hasratuddin. (2014). Pembelajaran Matematika Sekarang dan yang akan Datang Berbasis Karakter. Jurnal Didaktik Matematika Universitas Negeri Medan. Vol.1, No. 2, 2014, hal: 30-42.

Imran, Arsidaryani Putri. (2017). Analisis literasi matematika dan leyakinan matematik siswa SMA Negeri di Kota Kendari. Tesis UHO Kendari: tidak dipublikasikan.

Johar, Rahmah. (2012). Domain Soal PISA untuk Literasi Matematika. Jurnal Peluang, Volume 1, Nomor 1, Oktober 2012, ISSN: 2302-5158.

Mahdiansyah dan Rahmawati. (2013). Literasi Matematika Siswa Pendidikan
Menengah: Analisis Menggunakan Desain Tes Internasional dengan Konteks Indonesia. Jakarta: Badan Penelitian dan Pengembangan, Kemendikbud.

Maryanti, Era. (2012). Peningkatan Literasi Matematis Siswa melalui Pendekatan Metacognitive Guidance. Tesis pada Jurusan Pendidikan Matematika UPI Bandung: tidak diterbitkan.

OECD. (2009). Learning Mathematics for Life: a View Perspective from PISA. Diakses tanggal 10 Januari 2018 dari www.oecd.org

. (2016). Mathematics Framework PISA 2015. Diakses tanggal 10 Januari 2018 dari www.oecd.org

(2018). PISA 2015 Result in Focus. Diakses tanggal 10 Januari 2018 dari www.oecd.org

Ojose, Bobby. (2011). Mathematics Literacy: Are We Able To Put The Mathematics We Learn Into Everyday Use?.Journal of Mathematics Education, Vol. 4, No. 1, pp. 89-100, U.S.A. 